\title{
Correspondance
}

\section{Dealing with prostitution in Canada}

I take exception to CMAf's comments about "john school" in a recent editorial. ${ }^{1}$ To begin with, the "johns" are in fact exposed to direct feedback about the "public nuisance" aspects of prostitution, from community members whose neighbourhoods are negatively affected by street prostitution. I can assure you that from the community perspective, this problem is far greater than a simple "nuisance."

More important, characterizing john school as a "morality play on prostitution" is inaccurate. We do not try to impose moral standards on the johns. Instead, we leave it up to them to decide if prostitution fits within their own set of socially developed morals and values. We allow them to hear real people's stories about prostitution: police officers who see the damage daily, women who have been there and who are now trying to turn their lives around, a mother who has experienced the heartbreak of seeing her daughter in prostitution, community members who live with prostitution in their neighbourhoods and health care personnel who work with women on the streets. Are there moral issues here? Of course, but the johns are left to decide these issues for themselves.

\section{Ian Mitchell \\ Co-ordinator \\ Prostitution Offender Program \\ of British Columbia \\ John Howard Society of the Lower \\ Mainland of British Columbia \\ Vancouver, BC \\ Reference \\ 1. Prostitution laws: health risks and hypocrisy [ed- itorial]. CMAf 2004;171(2):109.}

DOI:10.1503/cmaj.1041292

$\mathrm{I}$ agree that Canada's prostitution laws need to be revamped, but CMA7's editorial $^{1}$ has missed the point. I'm not convinced that changing the laws will actually make people's lives safer. We need to change attitudes. The police in some cities, such as our own (Edmonton), have made great strides in changing how they enforce existing laws, but we need to look internationally for alternatives to current laws (e.g., Sweden).

There are many disadvantages to decriminalizing prostitution. In particular, there doesn't appear to be much thought going into what decriminalized prostitution would look like. For example, what will the Canadian government do to support those who have no choice about entering prostitution and would in fact prefer not to be in "the trade"?

$C M A \mathcal{7}$ has also missed a concern that lies at its own front door: systematic discrimination from doctors and other health care professionals. Having lived within the trade myself for over a decade and having talked with hundreds of women formerly and currently involved in "the life," I have heard countless stories of judgmental bedside manners by members of the medical profession.

The bottom line is that many women across this country would like to leave the street life, for a variety of reasons. We need to focus on these women and also make it safer for those who choose to remain. We need to get away from the flawed approach of decriminalization, by starting to think about ways of addressing the root causes that lead women to prostitution in the first place.

\section{Dawn Hodgins \\ Prostitution Awareness and Action \\ Foundation of Edmonton \\ Edmonton, Alta.}

\section{Reference}

1. Prostitution laws: health risks and hypocrisy [editorial]. CMA7 2004:171(2):109.

DOI:10.1503/cmaj.1041300

$\mathrm{T}$ he de facto criminalization of prostitution in Canada is an anachronistic remnant of this society's vigorous early20th century efforts to assert dominant moral ideology through the force of criminal law; similarly targeted behaviours include select substance use ("illicit drugs") and sexual orientation. ${ }^{1}$ However, as CMAf's editorial wisely outlines, ${ }^{2}$ the criminal law is a rather ineffective custodian of moral norms, especially when these are disobeyed by many and disagreed with by many more. Moreover, the ineffective criminalization of private conduct with implications for health can itself produce disastrous consequences, as the excessive human toll of the criminalization of substance use in North America illustrates. ${ }^{3,4}$ The prostitution issue is not much different: it is an ancient phenomenon that is here to stay; enforcement interventions are symbolic or of temporary displacement value at best; and the only sensible policy approach must be one grounded in pragmatic principles of public health. As our own research suggests, seemingly benevolent "reform" initiatives like john schools are essentially punishment in disguise for largely lower-class offenders, and thus serve to legitimize the status quo of criminalization rather than reforming it. ${ }^{5}$ It is thus a worthy and laudable cause for $C M A 7$ to argue for a public health based policy framework to deal with the sex trade issue. It is perhaps unfortunate for the prospects of this call as also shown by our research - that the public's opinion is more or less divided (as it is on many issues of morality control) on the question of whether sex for money should be controlled by punishment. ${ }^{6}$ This matter has thus become a political "no-winner," and law and policy reform will occur only if politicians are pressured to assume proactive and determined leadership, which may be poor in terms of potential vote gains but rich in merit for "good government" and public health.

\section{Benedikt Fischer}

Associate Professor

Public Health Sciences and Criminology

University of Toronto

Toronto, Ont.

\section{References}

1. Boyd N, editor. The social dimensions of law. Scarborough (ON): Prentice Hall Canada; 1986.

2. Prostitution laws: health risk and hypocrisy [editorial]. CMA7 2004;171(2):109.

3. Drucker E. Drug prohibition and public health - 25 years of evidence. Public Health Rep 1999; 114(1):14-29.

4. Fischer B. Canadian drug policy, 1985-1997: prohibition, public health and an open window. 